\title{
Impact of Some Animal Manures on Growth and Yield of Maize (zea mays l.)
}

\author{
Melese Damtew Asfaw \\ College of Natural and Computational Science, Mekdela Amba University, Ethiopia
}

\begin{abstract}
A field experiment to investigate the effects of application chicken, sheep and horse manure on the average yield and growth parameters of maize was carried out at the Research Farm of Woreillu Woreda, Ethiopia during 2017 planting season. Treatments were laid out in a Randomized Complete Block Design (RCBD) with three replications. The variables measured were plant height, number of leaves, leave area index (LAI), stem girth and grain yield obtained. Data collected were subjected to Analysis of Variance (ANOVA). The means were separated using LSD at five percent level of significance.Results obtained indicated that growth and yield of Maize was lowest in control treatments, which showed that the organic manures used in the study especially chicken manure positively influenced the performance and yield of Maize. The results also revealed that plots treated with chicken manure gave the highest number of leaves per plant, thicker stem, highest LAI and grain yield of $5.7 \mathrm{t} / \mathrm{ha}$. Comparatively, lesser grain yield of $4.2 \mathrm{t} / \mathrm{ha}$ was obtained with the application of horse manure. Sheep manure produced $3.9 \mathrm{t} / \mathrm{ha}$ of maize grain while the least yield of $2.8 \mathrm{t} / \mathrm{ha}$ of maize were recorded in the control treatments. Based on the findings of the experiments it could be deduced that chicken manure seems to promote higher growth yield of maize. Thus, it should be recommended for growers of maize crop in the study area.
\end{abstract}

Keywords: Organic manure, Growth parameter, Yield, maize.

DOI: $10.7176 / J N S R / 11-23-04$

Publication date: December $31^{\text {st }} 2020$

\section{Introduction}

Maize (Zea mays L., Poaceae) is the most important cereal in the world after wheat and rice with regard to cultivation areas and total production (Osagie and Eka, 1998). The name maize is derived from the South American Indian Arawak-Carib word mahiz. It is also known as Indian corn or corn in America (Purseglove, 1992). The plant is a source of food to mankind and feeds to animals and as well serves as raw material to many manufacturing industries in the production of materials such as starch, syrup, vegetable oil, and of recent use as biofuel (Remison, 2005). The crop can grow in different agro-climatic zones of the world, as such being referred to as versatile crop. No other crop has that suitability of growth in different zones like maize. For instance, it can grow from $58^{0} \mathrm{~N}$ to $40^{\circ} \mathrm{S}$, from below sea level up to higher than $3000 \mathrm{~m}$ above sea level, from low rainfall of $250 \mathrm{~mm}$ to $5000 \mathrm{~mm} /$ annum (Shaw, 1988).

The importance and use of maize differ from one country to another, as most developed nations use it as livestock feed, but with the breeding of new hybrid (saccharata) the crop is now being used as vegetable especially in advanced countries (Morris, 1998). Whereas, in the developing nations, the usage of it varies. Most of African and Latin Nations use it as food, while in the majority of Asian countries it's being cultivated for dual purpose (food and feed). About a quarter of the produced is being consumed globally as food (Doebley, 1990).

Food is one among the most important basic necessities of man. For Ethiopia, to meet the demand, need of its people and development goal in food production, food including maize must be readily available. Low soil fertility could threaten the security of food production and supply. Soil fertility is a major overriding constraint that affects all aspects of crop production (Mbah, 2006). In the past years, inorganic fertilizer was advocated for crop production to ameliorate low inherent fertility of soils in the tropics. In addition to being expensive and scarce, the use of inorganic fertilizer has not been helpful in intensive agriculture because it is often associated with reduced crop yield, soil acidity and nutrient imbalance (Ano and Agwu, 2005). The need to use renewable forms of energy and reduce costs of fertilizing crops has revived the use of organic fertilizers worldwide (Ayoola and Adeniyan, 2006).

Recycling animal manure for use as a low-cost organic fertilizer has resulted a positive effect on the growth and yield of a wide variety of crops and promoted the restoration of ecologic and economic functions of soil. The organic matter $(\mathrm{OM})$ content of animal manure is high and its addition to agricultural soils often improves soil physical, chemical, and biological properties Antonious (2016). Soil organic amendments alleviate OM that improves the properties of soils through increasing nutrient availability, water holding capacity, total pore space, aggregate stability, erosion resistance, temperature insulation, and decreasing soil density.

Crops like maize require nutrients such as $\mathrm{N}, \mathrm{P}, \mathrm{K}, \mathrm{Mg}, \mathrm{Ca}, \mathrm{Na}$, and $\mathrm{S}$ for good production. These nutrients are specific in function and must be supplied to the plant at the right time and in the right quantity for proper growth and reproduction (Adekiya and Ojeniyi, 2002). However, there is renewed interest in proper and effective use of organic manure to maintain soil fertility (Olatunji and Oboh, 2012). Aside from being source of plant 
nutrients, organic manure, e.g. poultry manure and animal dung has improved agricultural productivity in African countries. Organic manure helps to increase the population of soil micro-organisms which have some influence in protecting plant against pathogens like nematodes, soil born insects and also provides plant growth hormones like auxins (Agbede and Ojeniyi, 2009). Organic manure also helps to improve the physical condition of the soil and provides the required plant nutrients. It enhances cation exchange capacity and acts as a buffering agent against undesirable soil pH fluctuations (Akanni and Ojeniyi, 2008). The application of organic manure has been found to have higher comparative economic advantage over the use of inorganic fertilizer. Also, as a result of increased popularity of organic crop productions, more information is needed comparing the growth and yield of crops produced organically or using inorganic fertilizer. Hence, the objective of this study was to evaluate the effects of three different organic manure applications on the growth performance and yield potentials of maize grown in North-Eastern part of Ethiopia.

\section{Materials and methods}

Experimental site

The experiment was conducted at Research Farm of Woreillu Woreda, Northeastern part of Ethiopia during the 2017 planting season. The area lies at $39^{\circ} 25^{\prime} 45.9^{\prime \prime}$ E longitude and $10^{\circ} 35^{\prime} 2.7^{\prime \prime} \mathrm{N}$ latitude. The agro-climatic conditions of the area are moderate with an average altitude of $2730 \mathrm{~m}$ above sea level and the annual rainfall ranges from 766.2 to $1250 \mathrm{~mm}$ which is usually inadequate (short in duration), poorly distributed and highly variable in inter and intra seasons with temperatures ranging from $19-30^{\circ} \mathrm{C}$.

\section{Soil analysis}

Surface $(0-15 \mathrm{~cm})$ soil samples were taken over each site before start of experiment. The samples were bulked and air-dried for analysis. Organic matter (OM) was determined by Walkley-Black dichromate digestion method (Nelson and Sommers, 1982) and total soil nitrogen was determined by the kjeldahl method (Bremner and Mulvancy, 1982). Available P was determined by Bray-1 method and Exchangeable K, Ca and Mg was extracted using ammonium acetate. $\mathrm{K}$ was determined on flame photometer and $\mathrm{Ca}$ and $\mathrm{Mg}$ by EDTA titration. Soil $\mathrm{pH}$ values were obtained by using a HI9813-5 portable $\mathrm{pH} / \mathrm{EC} / \mathrm{TDS} /{ }^{\circ} \mathrm{C}$ meter (HANNA instruments, Romania, 2002).

\section{Field methods}

An experiment was laid out in a randomized complete block design (RCBD) with three replications to investigate the effect of different organic fertilizer on growth and yield maize. The experiments comprised of four treatments were as follows: Organic Manure $(\mathrm{CO}=\mathrm{Control}$ (absolute), i.e. no addition of manure or chemical fertilizer, $\mathrm{CM}$ $=$ Chicken Manure, $\mathrm{SM}=$ Sheep Manure, $\mathrm{HM}=$ Horse Manure. This gives a total of four treatments replicated three times to give a total of 12 experimental units. The size of a plot per treatment was $4 \mathrm{~m} \times 6 \mathrm{~m}$. Organic manures (about almost dry) were collected from farmers living in the study area. The manure, semi-decomposed, was point-applied in the planting beds 30 days before sowing maize, the test crop. The maize variety, 'Bahir Mashila', was sown three seeds per hill and thinned to two later at a spacing of $80 \mathrm{~cm} \times 50 \mathrm{~cm}$, giving a density of four plants $/ \mathrm{m}^{2}$. All the growth parameters (viz; plant height, stem girth, leaf length, leaf width, leaf area and leaf number) were taken at 3 weeks interval $(3,6,9$ and 12 weeks after planting) from planting to harvest.

\section{Cultural Practices}

\section{Fertilization}

The types of manures used were chicken manure, sheep manure and horse manure which was collected from the farmers of the study area and applied manually to the soil at 20t/ha before 30days from the sowing period on the bottom of the ridges mixed with soil and distributed equally to the entire plot using a hand hoe and then irrigated immediately.

Sowing

Sowing was done manually on one side of the ridge (eastern side of ridge) and it was carried out on February $11 / 02 / 2017$

Irrigation

Irrigation was applied immediately after sowing the plots; irrigation was applied twice on a weekly interval. Weeding

Weeds were controlled using hoe and hand pulling. Weeds were controlled twice, three weeks after sowing and just before fruiting.

Insect control

To prevent pest infestation, the insecticide thiodan, (endosulfan $\mathrm{C}_{9} \mathrm{H}_{6} \mathrm{C}_{16} \mathrm{O}_{3} \mathrm{~S}$ ) was applied two times during the growing period, at three weeks after sowing and during the flowering stage. 


\section{Character Studies}

The following parameters were measured during the study period.

1. Plant height $(\mathrm{cm})$ : Ten plants were randomly selected from the $2^{\text {nd }} \& 5^{\text {th }}$ ridges of each individual plot and the plants were tagged. The height of the plant was measured from the ten plants was recorded in $(\mathrm{cm})$. Plant height was measured at 3 week's interval (3, 6, 9 and 12 weeks after sowing) from sowing to harvest.

2. Number of leaves per plant: This parameter was measured by calculating all leaves of ten randomly selected plants at 3 weeks interval $(3,6,9$, and 12 weeks after sowing) from sowing to harvest. The mean number of leaves per plant was recorded.

3. Stem girth $(\mathrm{cm})$ : Measured by using a vernier (caliper) from the middle of the $2^{\text {nd }}$ inter-node of ten plants selected randomly from the $2^{\text {nd }} \& 5^{\text {th }}$ ridges of each plot and the mean stem girth were calculated.

4. Leaf area $\left(\mathrm{cm}^{2}\right)$ : Ten plants were chosen randomly from $2^{\text {nd }} \& 5^{\text {th }}$ ridges and the leaf area of the fourth leaf from the top was measured following the Stickler method (1961) using the following formula:

Leaf area $(\mathbf{L A})=$ length $\times$ maximum width $\times 0.75$.

5. Leaf area index (LAI): Leaf area index (L.A.I), a dimensionless quantity, is the leaf area (upper side only) per unit area of soil below. It is expressed as $\mathrm{m}^{2}$ leaf area per $\mathrm{m}^{2}$ ground area. Leaf area index was measured at 3 week's interval $(3,6,9$, and 12 weeks after sowing) from sowing to harvest using the following formula:

$$
\mathbf{L A I}=A P
$$

Where,

$Y=$ population of plants per plot

$N=$ average number of leaves

$A L=$ average area per leaf

$A P=$ area of plot

\section{Statistical Analysis}

Data collected were subjected to analysis of variance using the STATVIEW Software. Means were separated using Least Significant Difference (LSD) test. Correlation matrix was used to explore the relationship between crop growth and grain yield.

\section{Result and discussions}

The results of the physical and chemical analysis of the soil used prior to the commencement of the experiment are presented in table 1 . The results showed that the texture of the soil was sandy loam and was acidic in nature. The soils used for the experiment contains sand, silt and clay mixture and was low in organic matter, N, P, and CEC. The $\mathrm{pH}\left(\mathrm{H}_{2} \mathrm{O}\right)$ 5.3, Organic matter $1.78 \%$,Carbon $1.01 \%$ Total N 1.4\%, Available $\mathrm{P} 10.7 \mathrm{mg} / \mathrm{Kg}$, exchangeable $\mathrm{K}, \mathrm{Ca}$ and $\mathrm{Mg}$ being $0.28,7.9$ and $0.45 \mathrm{Cmol} / \mathrm{Kg}$ respectively and $\mathrm{CEC}$ of $6.7 \mathrm{Cmol} / \mathrm{Kg}$. This implies that the soil is poor in nutrients and of low productivity. Hence, response to organic manure would be encouraged Agbogidi and Okonmah (2012).

Table 1: physical and chemical properties of soil at study site

\begin{tabular}{|c|c|}
\hline Properties & Values \\
\hline $\mathrm{pH}$ & 8.3 \\
\hline Texture & Sandy loam \\
\hline Sand (\%) & 67.8 \\
\hline Slit (\%) & 26.8 \\
\hline Clay (\%) & 5.4 \\
\hline Organic matter (\%) & 1.78 \\
\hline Carbon (\%) & 1.01 \\
\hline Total N (\%) & 1.4 \\
\hline Available P (\%) & 10.7 \\
\hline Exchangeable Cations & Cmol/Kg \\
\hline Potasium & 0.28 \\
\hline Calcium & 7.9 \\
\hline Magnisium & 0.45 \\
\hline CEC & 6.7 \\
\hline
\end{tabular}

The chemical analysis of the applied manures (table 2) indicated that CM appeared to contain the highest values of organic matter and mineral nutrients $(\mathrm{N}, \mathrm{P}$, and $\mathrm{K})$ compared with other manure sources. This would probably have considerably increased the availability of mineral nutrients in the soil. Other researchers obtained similar results on organic amendments of soil (Boateng et al., (2006) and Islam et al., (2006). It was reported that chicken manure in contrast to chemical and other organic fertilizers, added organic matter to soil which improved 
soil structure, nutrient retention, aeration, soil moisture holding capacity and water infiltration (Deksissa et al., 2008). Other researchers claimed that CM significantly increased soil moisture content (Uwah et al., 2011) and reduced soil bulk density and soil compaction which ultimately increased porosity and water holding capacity of soils (Uwah et al., 2012).

It has been shown that, the continuous application of $\mathrm{CM}$ on some farmer's soil has led to a build-up of $\mathrm{P}$ exceeding 150-200 mg kg-1 (Penn et al., 2011). In addition, Silva and Menezes (2007) proposed that manure application was more effective to provide nutrients for plants because of its ability to prevent the immobilization of soil N (in short term) and increase the contents of available P and K soil over the period of culture. Phosphorous is the most important nutrient element, after $\mathrm{N}$, limiting agricultural production, and unlike nitrogen, $\mathrm{P}$ is less soluble in water and leaching is minimal. Hence, $\mathrm{CM}$ appeared to contain higher levels of $\mathrm{P}$ compared with other manure treatments (i.e. SM and HM), and a build-up of P in soils might have reached an agronomic optimum level. Animal manures were found to raise root-zone temperature to a favorable level, which promotes the rate of mineral uptake (AL-Hadi, 1987). Apart from the nutrients in manures, its effects on increasing P level and enhancing the biological life of the soil are well-recognized (Chang et al., 1990), particularly at high rates of application. Garg and Bahla (2008) reported that CM more readily supplies $P$ to plants than other organic manure sources.

In general, 90 to $100 \%$ of $\mathrm{K}$ in manure is available during the first year of application and the availability of $\mathrm{K}$ in manure is considered similar to that in chemical fertilizer since the majority of $\mathrm{K}$ in manure is in the organic form (Motavalli et al., 1989). The higher rate of K uptake by manure treated plants was ascribed to the activities of humus and folic acids; released by manures; in dissolving minerals that contain K (Elssa et al., 1995). Potassium is known to accumulate in the parts of plants in which cell division and growth occur. Plants require high amounts of $\mathrm{K}$ to sustain their physiological activities during flowering and yielding stages, thus the higher percentage of $\mathrm{K}$ found in the leaves of CM grown plants exhibited the higher rates of physiological activities and of $\mathrm{K}$ uptake by these plants. Our results suggest that the addition of manures to soils, and hence mainly CM at rate $20 \mathrm{t}$ ha- 1 , increased soil organic matter which might have promoted the increase in soil moisture contents and enhanced the mineralization process and released more nutrient into soil solution, consequently enhanced the uptake processes by plants.

Mineral nutrients which are steadily and gradually released at slower rates from this pool into the soil solution which can be extracted or mined by plant roots and utilized by the plant metabolic activates for growth and development throughout its life cycle. In contrast, chemical fertilizer placement exhibited different performance probably due to leaching loss of nutrients and or earlier and possibly shorter period of uptake by plants. It is suggested therefore, that placements of organic manure as fertilizer may be a more sustainable treatment, positively influenced the photosynthetic efficiency of manure grown plants, possibly because it maintained fertility status of the grown medium and ensured steadier supply of nutrients (i.e. N, P and K) to plant roots for absorption and utilization. It could be concluded that the uses of $\mathrm{CM}$ at the rate $20 \mathrm{t}$ ha-1 is a valuable alternate to chemical fertilizer for growth and development of maize plants. Economic benefits may be achieved if considering CM availability, sourcing and field applied at lower cost than chemical fertilizer.

\begin{tabular}{|c|c|c|c|c|c|c|c|c|c|c|}
\hline $\begin{array}{l}\text { Animal manure } \\
\text { source }\end{array}$ & $\begin{array}{l}\mathrm{C} / \mathrm{N} \\
\text { ratio }\end{array}$ & $\begin{array}{l}\text { O.C } \\
(\%)\end{array}$ & $\begin{array}{l}\text { O.M } \\
(\%)\end{array}$ & $\begin{array}{l}\mathrm{P} \\
(\%)\end{array}$ & $\begin{array}{l}\mathrm{N} \\
(\%)\end{array}$ & $\begin{array}{l}\mathrm{K} \\
(\%)\end{array}$ & $\begin{array}{l}\mathrm{Ca} \\
(\%)\end{array}$ & $\begin{array}{r}\mathrm{Mg} \\
\%)\end{array}$ & $\begin{array}{l}\mathrm{pH} \\
(\mathrm{H} 2 \mathrm{O})\end{array}$ & $\begin{array}{l}\text { EC (dsm-1, } \\
1: 5)\end{array}$ \\
\hline SM & 17.9 & 33.1 & 55.3 & 0.9 & 2.2 & 2.4 & 3.08 & 5.1 & 6.3 & 13.1 \\
\hline $\mathrm{CM}$ & 7.3 & 38.2 & 65.67 & 2.9 & 5.3 & 3.1 & 5.5 & 6.8 & 6.9 & 2.8 \\
\hline HM & 15.01 & 35 & 57.9 & 1.7 & 3.3 & 2.9 & 4.1 & 6.4 & 6.7 & 11.3 \\
\hline
\end{tabular}

\section{Effects of organic manure on maize plant height at different ages}

Table 3 shows the mean plant height of maize at 3WAS, 6WAS, 9WAS and 12WAS. The result indicates that treatment with chicken manure gave the highest mean plant height across the weeks. This was followed by horse and sheep manures while the control gave the least mean plant height. The Table also revealed that there were significant difference $(\mathrm{p}<0.05)$ among the treatments. This agrees with the assertion of Olatunji et al (2006) lay credence to this claim where okra and tomatoes grown in chicken manure performed better than their counterparts in other manure types. The increase of fertilization to the plant height was due to nitrogen in this manure, it resulted in taller plant because nitrogen found to increase number of nodes as well as internodes length and consequently plant height. This is agreement with that Hassan, (2002) who reported that chicken manure fertilizer significantly increased plant height. This is also line with results of Boateng et al. (2006) reported that poultry manure produced taller plants. This increase in plant height could be associated with continuous supply of nutrients by poultry manure (Farhad et al., 2009). Furthermore, enhancement of shoot apical meristem might be the reason behind achievement of better height. It seemed that application of chicken manure enhanced the activities of apical meristem, which, in turn led, to increase in height. Appreciable height in plants enhances better interception of solar energy, which will eventually aid photosynthesis. 
Increase in plant height was most effective and noticeable in plants treated with poultry manure due probably to adequacy of N (Sa-nguansak, 2004). The shorter plants response in untreated plots could be probably be related to insufficient $\mathrm{N}$ uptake as the plant had to rely on the native fertility of soil which was shown to be deficient in total N. This finding indicated that plant height is sensitive to adequate nutrient supply (Sharma, 1997). Plant height is an important growth character linked to the yield potential of a plant (Saeed et al., 2001).

Table 3. The Effect of the Treatments on the Mean Plant Height $(\mathrm{cm})$ of Maize

\begin{tabular}{|c|c|c|c|c|}
\hline Treatments & W3 & Weeks after sowing (WAS) & W6 & W9 \\
\hline CO & 31.7 & 71.33 & 82.67 & 88.67 \\
\hline CM & 77.3 & 141 & 182 & 183 \\
\hline SM & 60 & 110.7 & 126 & 136.7 \\
\hline HM & 71.9 & 118 & 149 & 152 \\
\hline LSD $(0.05)$ & $4.9 * *$ & $6.1 * *$ & $5.2^{* *}$ & $4.6^{* *}$ \\
\hline
\end{tabular}

** Significant at 5\% alpha level.

\section{Effects of organic manure on leaf production at different ages}

Table 4 shows the mean plant leaves of maize at 3WAP, 6WAP, 9WAP and 12WAP. The statistical analysis of the data (Table 4) showed that organic fertilizer significantly affected number of leaves per plant .The maximum number of leaves per plan was recorded in plots treated with chicken manure while the lowest number of leaves per plant was recorded in the control. The highest number of leaves per plant was recorded in the plot treated with chicken manure could be high nitrogen availability to the plant due to the application of chicken manure. The increase in the number of leaves per plant in chicken manure application due the direct role in plant nutrition the result also agree with Khalil et al.(2005)who reported that chicken manure having high nitrogen that improve the vegetative growth and make the nutrient available to the plant under stress condition. In addition, Michael et al. (2010) reported that poultry manure has been found to enhance the number of leaves in lettuce by providing sufficient amount of nutrients that accelerate the growth of leaves.

Increase in the number of leaves per plant occasioned by fertilizer application is bound to affect the plant growth and vigor positively. This is because leaves are the major organs of photosynthesis on plants. Increase in the number of leaves was a precursor to greater amount of assimilates and this allowing more translocation to the grain. Moreover, higher number of leaves on fertilizer treated plants contributes to production of better canopy and efficient suppression of weeds.

Table 4. The Effect of the Treatments on the number of leaves per plant of maize

\begin{tabular}{|l|c|c|c|c|}
\hline & Treatments & \multicolumn{4}{c|}{ Weeks after sowing (WAS) } \\
\hline CO & W3 & W6 & W9 & W12 \\
\hline CM & 9 & 22 & 34 & 40.5 \\
\hline SM & 14 & 30 & 51 & 64.3 \\
\hline HM & 10.8 & 23.2 & 40.1 & 53.7 \\
\hline LSD ( 0.05) & 12.2 & 26.5 & 45.8 & 58 \\
\hline
\end{tabular}

** Significant at 5\% alpha level.

\section{Effect of organic manure on maize stem girth at different ages}

The interaction among CO, CM, SM and HM was significant $(p \leq 0.05)$ at $3 \mathrm{WAS}, 6 \mathrm{WAS}, 9 \mathrm{WAS}$ and 12 WAS. This implies that the treatment components were interdependent for the significant enhancement of plant girth. Therefore, chicken manure that produced the thicker plant girth at the end of the growth period was the best treatment for plant girth size (Table 5). Only chicken manure treated plants had the thicker stem compared to the other treated and untreated plants. This observation is in agreement with previous report of Ayoola and Adeniran (2006) that variation in nutrients source among treatments will result in a significant variation on stem girth per plant.

The increase in the girth was not a product of secondary thickening because the plant is a monocot. Rather, it might have stemmed out of increase mitotic cell division in the stem as well as cell enlargement which then created a big sink in the stem for photo-assimilate storage. It could be said that mitotic cell division has been enhanced by better supply of nutrients through the application of poultry manure. When the enlarged cells were filled after cell division and enlargement, expansion of stem girth resulted. Since higher nutrient is needed for this process, low plant density became the choice for the achievement of this goal. This increase in stem girth enhanced production of higher straw yield. It is also advantageous if the targets of the production are hay and silage. Finally, better stem girth strengthens and protects plants against lodging.

In general, the result shows that treatments with organic manures gave the highest mean stem girth of maize 
across the weeks as compared to the control. This agrees with the finding of Anon (2002) who opined that organic manure is an excellent fertilizer material because of its high nitrogen, phosphorous and potassium contact and it is readily available than the mineral fertilizer and its effect on the soil is stable, slow in releasing nutrition to crop and also improving the soil physical and chemical properties.

Table 5. The Effect of the Treatments on the Mean stem girth $(\mathrm{cm})$ of maize

\begin{tabular}{|c|c|c|c|c|}
\hline Treatments & W3 & Weeks after sowing (WAS) & W12 \\
\hline CO & 9 & 22 & W9 & 34 \\
\hline CM & 14 & 30 & 51 & 64.3 \\
\hline SM & 10.8 & 23.2 & 40.1 & 53.7 \\
\hline HM & 12.2 & 26.5 & 45.8 & 58 \\
\hline LSD (0.05) & $1.3^{* *}$ & $2.9^{* *}$ & $1.7^{* *}$ & $1.3^{* *}$ \\
\hline
\end{tabular}

** Significant at $5 \%$ alpha level.

\section{Effect of organic manure on maize leaf area index at different ages}

The data regarding LAI is presented in Table 6 . The statistical analysis of the data showed that organic fertilizers significantly affect leaf area index. The highest was recorded in plots treated with chicken manure while the lowest LAI was recorded in plots treated as control. The highest LAI was recorded in plots treated with chicken manure could be due to efficient nitrogen availability as a result the plant uptake more nitrogen and in turn larger leaves were observed. Nitrogen element was reported to increase leaf area index through the increase in leaf length and width (Rogheb et al., 1990) and leaf blade size (Kabbashi and Nagatomo, 1953). This result is in agreement with Omer (1994) and Abaro (1992) reported that leaf area index increased with fertilizers. The results also agreed with the Balyeri et al.(2016) they studied that Poultry manure influenced growth, yield and nutritional quality of containerized aromatic pepper (Capsicum annuum L., var 'Nsukka Yellow'). They concluded that the poultry manure increased the LAI due to sufficient nitrogen availability, which in turn improve the vegetative growth of the crop. these finding are also confirmed by Mulebo et al. (1983) who found greater leaf area index with the application of poultry manure.

Higher LAI signify greater leaf production rates, leaf area expansion and leaf area duration and could signify the relative amount of light intercept by plant. The LAI of any plant is a measure of the capacity of the photosynthetic system of translocation. The increase in LAI resulting from fertilizer application led to higher dry weight accumulation.

Table 6. The Effect of the Treatments on LAI of maize

\begin{tabular}{|c|c|c|c|c|}
\hline Treatments & Weeks after sowing (WAS) & W6 & W12 \\
\hline CO & W3 & W6 & 0.62 & 1.12 \\
\hline CM & 0.024 & 0.22 & 2.5 & 4.6 \\
\hline SM & 0.141 & 1.3 & 1.2 & 2 \\
\hline HM & 0.061 & 0.59 & 1.6 & 3 \\
\hline LSD (0.05) & 0.082 & 0.72 & $0.05^{* *}$ & $0.18^{* *}$ \\
\hline
\end{tabular}

** Significant at 5\% alpha level.

\section{Effects of organic manure on yield of maize}

Grain yield is a function of interaction among various yield components that was affected differentially by the growing conditions and crop management practices. There a significant difference $(\mathrm{P}<0.05)$ in grain yields within the treatments (table 7). Grain yields increased in the order $\mathrm{CM}>\mathrm{HM}>\mathrm{SM}>\mathrm{CO}$ with increments of $203.5 \%, 150 \%$ and $139.3 \%$ over the control (CO) respectively. These results are in accordance with the findings of Boateng et al. (2006) that poultry manure significantly increased the grain yield.

Table 7. Average grain yield of maize during the planting season

\begin{tabular}{|c|c|}
\hline Treatments & Average Yield t/ha \\
\hline CO & 2.8 \\
\hline CM & 5.7 \\
\hline SM & 3.9 \\
\hline HM & 4.2 \\
\hline LSD (0.05) & $0.08^{* *}$ \\
\hline
\end{tabular}

** Significant at 5\% alpha level.

In general, Mohanty et al., (2006) suggested that organic manure contribute to plant growth through their favorable effects on the physical, chemical and biological properties of soil presumably due to chelating of cations by organic acids and other decay products. It may be suggested that when crop improvements with manure were 
greater than those attained with chemical fertilizer, response was usually attributed to improved soil conditions not provided by chemical fertilizer. The superiority of CM to the other sources of organic manure in producing taller plants with higher number of leaves, more leaf area index and grain yield may be attributed to good and slow release balanced nutrients and low $\mathrm{C} / \mathrm{N}$ ratio (table 2) which support plant growth.

\section{Correlation Analysis}

Table 8 shows the correlation, matrix among some yield attributes and grain yield evaluated under the fertilizer treatments. There was a significant positive correlation between plant height with stem girth, number of leaves, LAI, and grain yield, number of leaves with LAI and grain yield and LAI with grain yield. . Correlation analysis for yield and yield components showed that grain yield had reasonable association with most of the traits measured. Table 8. Correlation analysis among yield attributes of maize

\begin{tabular}{|c|c|c|c|c|c|}
\hline & Plant height & Stem girth & Number of leaves & Leave area Index & Grain yield \\
\hline Plant height & 1 & $0.981 * *$ & $0.702 *$ & $0.873^{*}$ & $0.798^{*}$ \\
\hline Stem girth & & 1 & $0.654 *$ & $0.801 * *$ & $0.653^{*}$ \\
\hline Number of leaves & & & 1 & $0.869 *$ & $0.774^{*}$ \\
\hline Leave area Index & & & & 1 & $0.786^{* *}$ \\
\hline Grain yield & & & & & 1 \\
\hline
\end{tabular}

\section{Conclusions}

In this experiment, animal manure was found to be a labile pool for essential mineral nutrients which are steadily and gradually released at slower rates from this pool into the soil solution which can be extracted or mined by plant roots and utilized by the plant metabolic activates for growth and development throughout its life cycle. The study showed that the yield of maize can be increased with animal manure application to ensure food sustainability. The different manure types at equal applied rates provided equivalent amount of nutrients to plants. Based on ease of availability, collection and nutrient composition and nutrient composition, poultry manure is thereby suggested for maize growers for higher yield per hectare in the humid ultisols environment.

\section{References}

Abaro, M.B. (1992). The Effect of agroforestry techniques on the growth and yield of sorghum (Sorghum bicolor) variety abusabien. M.Sc. Thesis. Fac. of Agric. University of Khartoum, Sudan.

Agbede, T. M. and Ojeniyi, S.O. (2009). Tillage and poultry manure effects on soil fertility and sorghum yield in southwestern Nigeria. Soil and Tillage Research, 64: 209-215.

Agbogidi, O. M, and Okonmah, C. U. (2012). Growth and Yield of Maize as Influenced by Organic Manure type in a Niger Delta.

AL-Hadi, S. S. (1987). Some effects of the influence of soil porosity on soil water content, soil water flux and soil water use. PhD. Dissertation, the Victoria University of Manchester.

Ano, A. O. and Agwu. J.A. (2005). Effect of animal manures on selected soil chemical properties (1). Nigerian Journal of Soil Science, 15: 14-19.

Anon (2002). Agriculture issue on compost controversy. Acres U.S.A.

Antonious, G.F. (2016). Organic fertilizers: From basic concepts to applied outcomes. In:

Ayoola, O. T. and Adeniyan, O.N. (2006). Influence of poultry manure and NPK fertilizer on yield and yield components of crops under different cropping systems in southwest Nigeria. African Journal of Biotechnology, 5 (15): 1386-1392.

Balyeri, P.K., Otitoju, G.T., Abu, N.E. and S. Umeh, S. (2016). Poultry manure influenced growth, yield and nutritional quality of containerized aromatic pepper. Afr. J. Agric. Res. 11(23): 2013-2023

Chang, C., Summerfield, T.G. and Entz, T. (1990). Rates of soil chemical changes with eleven annual applications of cattle feedlot manure. Can. J. Soil Sci., 70: 673-681.

Doebley, J. (1990). Molecular evidence for gene flow among Zea species, Journal of Bio Science, 40(6): 443-448.

Elssa, A. M, Abou-Hadid, A.F. and Saleh, M.M. (1995). Increasing productivity of land irrigated by marginal quality water through use of organic manure in Egypt. pp: 95-110.

Hassan, E.A.H. (2002). Effect of chicken manure and season on the performance and HCN Content of two Forage sorghum cultivar, Ph.D. Thesis, Faculty of Agriculture, University of Khartoum, Sudan.

Kabbashi, Y. and Nagatoma, T. (1953). Yield of soiling maize under the influence of continuous application of farmyard manure.Herbage Abst. 53(5):1852 - 1857.

Khalil, M.I., Schmidhalter, U and Gutser, R. (2005). Turnover of chicken manure in some upland soils of Asia: Agricultural and Environmental Perspective. Proc. Intl. Workshop, January 2005, Hamburg. pp: 275-292.

Mbah, C. N. and J. S. Mbagwu. (2006). Effect of animal waste on physicochemical properties of a dystric leptosol 
and maize yield in Southeastern Nigeria, Nigerian Journal of Soil Science.

Michael T., Phiwokwakhe, D., Wahome, P.K. and Oseni, T.O. (2010). Study the Effects of organic fertilizers on growth, yield, quality and sensory evaluation of red lettuce.Abjna. 1(6): 1319-1324.

Mohanty, M, Painuli, D.K., Misra, A.K. and Ghosh, P.K. (2006). Soil quality effects of tillage and residue under rice-wheat cropping on a Vertisol in India. Soil \& Tillage Research 92 (2007) 243-250.

Motavalli, P.P., Kelling, K.A. and Converse, J.C (1989). First-year nutrient availability from injected dairy manure. J. Environ. Qual., 1: 180-185.

Mulebo N., Hort T. G. and Paulsen G. M. (1983). Physiological factors affecting maize yields under tropical and temperate conditions. Trop. Agric. (Trin.) 60: 3-10.

Nelson, D.W. and Sommers, L.S. (1982). Total Carbon, organic carbon and organic matter. In: Page, A.L. et al (Eds.), Method of Soil Analysis Part 2. Agron. Monogr. 9 (2nd edition), ASA and SSSA, Madison, Wsc. pp 539-579.

Olatunji, U. S., Ayuba, A. and Oboh V. U. (2006). Growth and yield of Okra and Tomatoes as affected by pig dung and other organic manure. American Journal of Plant Physiology, 1 (2):78-85.

Omer, E. (1994). Effect of farmyard manure and urea fertilization on growth and yield of teff grass (Eragrostis Tiff. Z. ucc.) M.Sc. Thesis. Fac. of Agric. University of Khartoum, Sudan.

Purseglove, J.W. (1992). Tropical Crops: Monocotyledons. Longman Scientific and Technical, New York. pp. 300-305.

Rogeb, M.M. Rassay, H.W. and ElShazly. M. (1990). Vegetative growth and dry matter accumulation. Field crop abstracts 43: 12, Abstract 8615.

Saeed, I.M., Abbasi, R. and Kazim, M. (2001). Response of maize (Zea mays) to nitrogen and phosphorus fertilization under agro-climatic condition of Rawalokol, Azad Jammu and Kaslim and Kashmir, Pakistan Journal of Biological Science, 4: 949-952.

Sharma, A.R. and Mittra, B.N. (1991). Effect of different rates of application of organic and nitrogen fertilizers in a rice-based cropping system. Journal of Agricultural Science, 117:313-318

Shaw, R.H. (1988). Climate requirement, in Sprague, G.F. and Dudly, J.W (Ed), Corn and Corn 638 Improvement, 3rd ed Madism, Wisconsin, WI, pp. 609.

Silva, T.O. and Menezes, R.S. C. (2007). Organic fertilization of potato with manure and, or crotalaria iuncea. II. Availability of N, P and K in the soil along the crop cycle. Reviste. Brasileiria de clencia do solo, 31: 51-61.

Stickler, F.C., Wearden, S. and Pouli W. (1961). Leaf area determination in grain Sorghum. Agron. J., 53: $187-$ 189.

Uwah, D.F., Eneji, A.E. and Eshiet, U.J. (2011). Organic and mineral fertilizers effects on the performance of sweet maize (Zea mays L.) in southeastern rainforest zone of Nigeria. Int. J. Agric. Sci., 3(1): 54-61.

Adekiya, A.O. and Ojeniyi, S.O. (2002). Evaluation of tomato growth and soil properties under methods of seedling bed preparation in an Afisol in the rainforest zone of southwest, Nigeria. Soil and Tillage Research, 64: $275-279$.

Akanni, D.I. and Ojeniyi, S.O. (2008). Residual effect of goat and poultry manures on soil properties, nutrient content and yield of Amaranthus in southwestern Nigeria. Research Journal of Agronomy, 2: 44-46.

Baoteng, S.A., Zickermann, J. and Kornaharens, M. (2006). Effect of poultry manure on growth and yield of maize. West African. J. Appl., 9: 1-11.

Bremner, J.M and. Mulvancy, C.S. (1982). Nitrogen-Total. In: Page, A.L et al (Eds,), Methods of soil analysis Part 2, Agron Monogr. 9 (2nd edition) ASA and SSSA, Madison, Wsc, pp. 403-430.

Deksissa T., Short, I. and Allen, J. (2008). Effect of soil amendment with compost on growth and water use efficiency of Amaranth. In: Proc. of the UCOWR/NIWR Annual Conf. Int. Water Res. Challenges for the 21 st Century and Water Resources Education, Durham, NC.

Farhad, W., Saleem, M.F., Cheema, M.A. \& Hammad, H.M. (2009). Effect of poultry manure levels on the productivity of spring maize (Zea mays L.). The JAPS, 19(3):122-125.

Garg, S. and Bahla, G.S. (2008). Phosphorus availability to maize as influenced by organic manures and fertilizer $\mathrm{P}$ associated phosphorous activity in soils. Bio resource Tech., 99(13): 5773-5777.

Islam, M.M., Majid, N.M., Karim, A.J.M., Jahiruddin, M., Islam, M.S., Mbah, C.N. and Mbagwu, J.S.C. (2006). Effect of animal waste on physicochemical properties of a dystric leptosol and maize yield in Southeastern Nigeria. Nigerian Journal of Soil Science, ISSN: 1597-4488.

Larramendy ML, Soloneski S, editors. Soil Amendments for Agricultural Production.

Moriss, M.L. (1998). Overview of the world maize economy, in Morris, M.L. (Ed), Maize Seed Industries in Developing Countries, Lynne Rienner, Boulder, Colarado, pp. 13-34.

Olatunji, O. and Oboh, V.U. (2012). Growth and yield of okra and tomato as affected by pig dung and other manures issue for economic consideration in Benue State. Nigerian Journal of Soil Science, 22:103-107.

Osagie, A.U. and Eka, O.U. (1998). Nutritional Quality of Plant Foods. Post-Harvest

Penn, C.J., Vitale, J., Fire, S., Payne, J., Warren, J.G., Zhang, H., Eastman, M. and Herros, S.L. (2011). Alternative 
poultry litter storage for improved transportation and use as soil amendment. J. Environmental Quality. In print.

Remison, S.U. (2005). Arable and vegetable crops of the tropics. Gift-Press Association, Benin City, Nigeria. Research Unit, University of Benin, Benin. pp. $34-41$.

Rijeka, Croatia: Intech, pp. 157-187.

Sa-nguansak, D.A. (2004). Effect of nitrogen fertilizer on nitrogen assimilation and seed quality of Amaranth (Amaranthus spp.) and Quinoa (Chenopodium quinoa Wild). Dissertation for the Degree of Doctor of Agricultural Science, University of Gottingen.

Uwah, D.F., Ukoha, G.O., Iyango, J. (2012). Okra performance and soil and water conservation as influenced by poultry manure and organic mulch amendments. J. Food, Agri. and Environment, 10(1): 748-754. 